\title{
Clozapine in the Treatment of Aggression in Conduct Disorder in Children and Adolescents: A Randomized, Double-blind, Controlled Trial
}

\author{
Myrthala Juárez-Treviño ${ }^{1}$, Antonio Costilla Esquivel ${ }^{2}$, Lilia Marytza Leal Isida ${ }^{3}$, Dionicio Ángel Galarza Delgado ${ }^{4}$, \\ Manuel E. de la O Cavazos ${ }^{5}$, Lourdes Garza Ocañas $^{6}$, Rosalinda Sepúlveda Sepúlveda ${ }^{7}$ \\ Departments of ${ }^{1}$ Psychiatry, ${ }^{4}$ Internal Medicine, ${ }^{5}$ Pediatrics, and ${ }^{6}$ Pharmacology, Hospital Universitario, Universidad Autónoma de Nuevo León, \\ ${ }^{2}$ Unidad Monterrey, Centro de Investigación en Matemáticas CIMAT, ${ }^{3}$ Department of Psychiatry, Instituto Tecnológicoy de Estudios Superiores \\ de Monterrey ITESM, Escuela de Medicina, NL, Mexico, ${ }^{7}$ Department of Environmental Health, Harvard T. H. Chan School of Public Health, \\ Boston, MA, USA
}

\begin{abstract}
Objective: This study was conducted to compare the efficacy of clozapine vs. risperidone in the treatment of aggression in conduct disorder in children and adolescents.

Methods: Twenty-four children with conduct disorder aged 6 to 16 years were randomized in a prospective, double-blind trial into two groups to receive clozapine or risperidone for 16 weeks. The Modified Overt Aggression Scale score was used as the primary outcome of the study. Secondary outcomes were Child Behavior Checklist (CBCL) externalization (CBCL-E) and internalization factors; Aggression, Hyperactivity and Delinquency subscales of CBCL-E, Child Global Assessment Scale (CGAS), Barnes Akathisia Rating Scale, and Simpson-Angus Scale.

Results: Both antipsychotics were similarly effective in the primary outcome and in most of the secondary ones. Clozapine was more effective in CBCL-E, the delinquency subscale and the CGAS scores than risperidone $(p=0.039$, 0.010, and 0.021). Two subjects from the clozapine group were excluded due to a low neutrophil count at week four.

Conclusion: Clozapine and risperidone are effective for short-term treatment of aggression in children and adolescents with conduct disorder. Clozapine was more effective than risperidone in conduct externalization factors, delinquency trait and global functioning in children and adolescents. Stronger efficacy of clozapine should be investigated in larger sample sizes using pharmacogenomic studies. White blood cell counts need to be monitored when prescribing clozapine.
\end{abstract}

KEY WORDS: Clozapine; Risperidone; Conduct disorder; Child; Adolescent.

\section{INTRODUCTION}

Disruptive behavior disorders frequently precede antisocial personality disorder, substance abuse, and delinquency. Aggression and severe behavioral problems are related to difficulties in social, family, and academic performance and in personal development. ${ }^{1)}$ These are fre-

Received: January 19, 2018 / Revised: March 22, 2018

Accepted: March 23, 2018

Address for correspondence: Myrthala Juárez-Treviño, PhD Department of Psychiatry, Hospital Universitario, Universidad Autónoma de Nuevo León, Río Orinoco \#304 Ote. Col. Del Valle, San Pedro Garza García, NL, CP 66220, México

Tel: +52-8181150083, Fax: +52-8183476147

E-mail: dramyrthalajuarez@yahoo.com

ORCID: https://orcid.org/0000-0002-6414-8560 quent reasons to refer a youth to a child psychiatrist. ${ }^{2)}$ Early treatment of the aggression component in conduct disorders may lead to a better prognosis. ${ }^{3,4)}$

The prevalence of conduct disorder varies from $2 \%$ to $10 \%$ in community studies. ${ }^{5)}$ In Mexico, the prevalece of conduct disorder has been reported as $6 \%$ to $16 \%$ for males and $2 \%$ to $9 \%$ for females.

Individual factors, such as domestic violence, and contextual factors in early parenting may place children at increasead risk for the development of aggression. ${ }^{7)}$

Atypical antipsychotics (risperidone, olanzapine, quetiapine, aripiprazole, clozapine, amisulpiride, sertindole, ziprasidone, zotepine, paliperidone, asenapine and iloperidone) have been used off-label for the treatment of ag-

(c) This is an Open-Access article distributed under the terms of the Creative Commons Attribution Non-Commercial License (http://creativecommons.org/licenses/by-nc/4.0) which permits unrestricted non-commercial use, distribution, and reproduction in any medium, provided the original work is properly cited. 
gression in conduct disorders. ${ }^{1,8-16)}$

Pappadopulos et al.' de developed in 2003 their Treatment Recommendations for the Use of Antipsychotics for Aggressive Youth (TRAAY), reporting evidence of the use of atypical antipsychotics for agression in youth, and recommended double-blind trials to examine the safety and efficacy of atypical antipsychotics compared to each other, among other strategies for further knowledge on this frequent clinical problem.

A year later, Cheng-Shanon et al. ${ }^{10)}$ reviewed the literature on second-generation antipsychotic medications in children and adolescents, identifying 176 reports including 15 double-blind controlled trials, 58 open-label, 18 retrospective chart reviews and 85 case series/reports. Forty-three percent of them reported on the use of risperidone, making a case for risperidone to be the gold standard. They found evidence suggesting that these antipsychotics are efficacious in the treatment of psychosis, bipolar disorders, pervasive developmental disorders and Tourette's disorder, and are potentially useful in mental retardation, conduct disorder and severe attention deficit hyperactivity disorder (ADHD). ${ }^{10)}$

Clozapine reduces the clinical severity of antisocial personality disorder in adults. It reduces impulsive-behavioral dyscontrol, anger, aggression and violence, specially at low doses. ${ }^{17)}$ Clozapine is the gold standard in treatment of resistant schizophrenia. ${ }^{18)}$ and it has also been used for the management of aggression in schizophrenia, treatment-resistant bipolar disorder, intermittent explosive disorder, posttraumatic stress disorder, autistic spectrum disorders, borderline personality disorder, learning disabilities, and severe conduct disorder. ${ }^{12,15,19-25)}$

There is consistent evidence that clozapine is more effective and more rapidly controls aggression and psychotic symptoms than other antipsychotics in schizophrenia, personality disorders, affective disorders, substance abuse, mental retardation, childhood disintegrative disorder and autism ${ }^{20,23-27)}$ and it does not cause serum prolactine increases nor dyskinesia due to its neuroreceptor binding profile. ${ }^{27-29)}$ However, it is not frequently considered for the treatment of aggressive behavior in conduct disorder, due to concerns about its well known haematological toxicity even though hematological adverse events are not a frequent cause of therapy discontinuation. $^{30)}$

Teixeira et al. ${ }^{15,16)}$ in 2013 reported an open, natural- istic observational study with a sample of 7 boys between 10 and 14 years of age diagnosed with conduct disorder and treated with clozapine. To their knowledge, there was no previous reported use of clozapine in the treatment of conduct disorder. They showed no significant side effects or hematological changes. The improvement in patterns of aggression in six out of seven patients with severe conduct disorder reinforces previous studies that evaluated clozapine as a treatment for children and adolescents with aggressive behavior for schizophrenia, mental retardation and autism. ${ }^{15,16,21,22)}$ This suggests that clozapine may be useful for reducing aggression in general, not only limited to specific diagnostic groups. ${ }^{16)}$ Clozapine in modest doses appear to have clinical benefits for adolescents with bipolar disorder, intermittent explosive disorder and posttraumatic stress disorder with an off-labeled indication. $^{19)}$

The incidence of clozapine-induced agranulocytosis does not exceed that of conventional antipsychotic drugs, for which no lifelong white blood cell counts are required. ${ }^{30)}$ Although, continue vigilance is needed, just the way it is for chlorpromazine, quetiapine and amisulpride as potential neutropenia inductors. Three are the possible mechanisms of clozapine-induced neutropenia/ agranulocytosis: immune-mediated response, apoptosis of neutrophils and direct toxicity against the bone marrow stromal cells (demonstrated only in vitro). ${ }^{31)}$ This effect seems to be more due to a heritable, polygenic trait. ${ }^{32-34)}$

Risperidone is one of the most studied antipsychotics in the treatment of aggression in children and adolescents with disruptive behavior disorders. ${ }^{135-42)}$ There is evidence to support its clinical efficacy for the treatment of aggressive behaviour in youth with oppositional defiant disorder (ODD) and conduct disorder, with and without ADHD. ${ }^{1,4)}$ Two retrospective studies of short-term low-dose long-acting risperidone use in treatment compliant youth cases with conduct disorder showed its effectiveness and safetyness. $^{43,44)}$

There are limited studies available. In 2015, Pringsheim et al. ${ }^{4)}$ published a meta-analysis where eleven placebocontrolled randomized clinical trials of antipsychotics for the treatment of aggression in youth with ADHD, ODD, and conduct disorder were found: four studied risperidone in youth with subaverage intelligence quotient (IQ), 3 studied risperidone in youth with average IQ, 1 studied evaluated maintenance treatment with risperidone in- 
cluding both youth with subaverage IQ and youth with average IQ, 1 studied quetiapine, 1 studied haloperidol and 1 studied thioridazine in youth with subaverage IQ. All studies of risperidone reported a significant benefit on disruptive and aggressive behaviour (eight). Three studies showed low-quality evidence of their effect on aggressive behaviour due to the use of nonspecific rating instruments to evaluate conduct problems. ${ }^{4)}$

The aim of this study was to compare the efficacy of clozapine versus risperidone, the gold standard for treatment of aggression in children and adolescents with conduct disorder. It is of note that ethical considerations preclude approval by local institutional review boards (IRB) of placebo use in a youth population study, due to the unnecessary risk of behavioral exacerbation if they received no active treatment. However, as previously discussed, risperidone has a solid set of studies attesting its effectiveness and safety for conduct disorder aggression and was therefore used as an active comparator.

\section{METHODS}

\section{Subjects}

Subjects with aggressive conduct were invited for screening during their clinical visit at the Hospital Regional de Alta Especialidad Materno-Infantil in Monterrey, Mexico. Sixty-five subjects between 6 and 16 years old, with criteria for conduct disorder according to the Diagnostic and Statistical Manual of Mental Disorders 4th edition, text revision (DSM-IV-TR) ${ }^{45)}$ were assessed for eligibility. The study was previously reviewed and approved by the local
IRB (Ethics and Research Committee of the Hospital Regional de Alta Especialidad Materno-Infantil; Registration no. 06/2014) and registered at the Central TrainingHealth Research and Quality of the State Institute of Health of Nuevo Leon, Mexico (File no. 19011401).

Inclusion criteria were an intellectual coefficient $>70$, normal laboratory blood tests, and a normal electroencephalogram. In order to participate, patients assented and parents/guardians consented to participate, and keep all follow-up visits. Patients with a diagnosis of a major neurological, psychotic or bipolar disorder, drug abuse and/or pregnancy were excluded. Any laboratory abnormalities such as a hemoglobin $\leq 10 \mathrm{~g} / \mathrm{dl}$; a leukocyte count $\leq 4,000 \mathrm{~K} / \mu \mathrm{l}$; an absolute neutrophil value $\leq 1,500$ $\mathrm{K} / \mu \mathrm{l}$; a platelet count $\leq 150,000 \mathrm{~K} / \mu \mathrm{l}$; and a glycemia $>120$ $\mathrm{mg} / \mathrm{dl}$ were also a cause for exclusion. If during the study, the absolute neutrophil cell count decreased $>50 \%$ of baseline, the subject was excluded and medication was stopped immediately. If the patient was using an antipsychotic, a two-week washout period was applied prior to randomization.

If ADHD was present at screening, subjects were then treated with methylphenidate, and if conduct disorder symptoms remitted after 2 weeks of treatment subjects were excluded. It was considered that symptoms were due to impulsivity more than dissocial issues (Fig. 1). Subjects with ADHD treated with stimulants were allowed to participate if they were treated for 2 weeks prior to randomization and disruptive behavior persisted (Table 1). All of the participants who received methylphenidate were males.

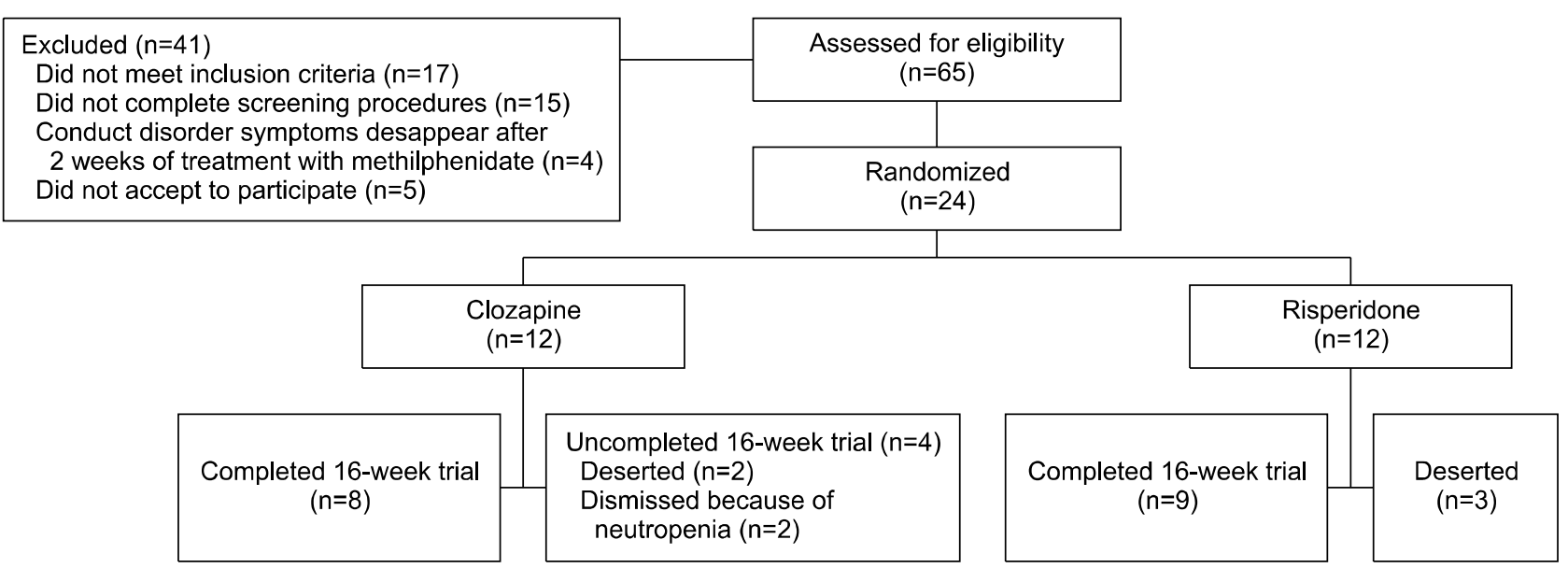

Fig. 1. Diagram of recruitment and retention of subjects along the trial. 


\section{Clinical Assessments}

Subjects who met inclusion criteria and agreed to be screened had a physical and neurological examination. Reynolds Intellectual Assessment Scale, blood tests and an electroencephalogram were also performed. Clinical assessments included three of the mostly used scales in clinical trials: the Modified Overt Aggression Scale $(\mathrm{MOAS})^{46-48)}$, the Child Behavior Checklist parents version 4-16 (CBCL 4-16) ${ }^{49)}$ and the Children's Global Assessment Scale (CGAS) ${ }^{50)}$ at baseline, and after 4, 8, 12 and 16 weeks of treatment. Blood tests were done at 2, 4, 8 , and 16 weeks of treatment. Barnes Akathisia Rating Scale (BARS) $)^{51)}$ and the Simpson-Angus Scale (SAS) ${ }^{52)}$, vital signs, weight, and height were recorded at all the visits.

MOAS was the primary outcome measure used to determine the effect of clozapine. Secondary outcomes were $\mathrm{CBCL}$ externalization factor (CBCL-E), CBCL internalization factor (CBCL-I); Aggression, Hyperactivity and Delinquency subscales of CBCL; CGAS, BARS, and SAS.

\section{Randomization and Treatment}

In this 16 week-double blind clinical trial, subjects were scheduled for 8 visits: baseline, on weeks 1, 2, 4, 6, 8,12 , and 16 . Sixty-five subjects were evaluated. Twentyfour met inclusion criteria and were randomized to receive either $0.3 \mathrm{mg} / \mathrm{kg}$ of clozapine or $0.025 \mathrm{mg} / \mathrm{kg}$ of risperidone on the first visit. Twelve subjects received clozapine and twelve received risperidone (Fig. 1). Doses were increased to $0.6 \mathrm{mg} / \mathrm{kg}$ for clozapine and $0.05 \mathrm{mg} / \mathrm{kg}$ of risperidone during visit 2 (week 1) and were maintained until completion of the trial. Route of administration was by mouth. It is worth mentioning the reasoning behind this dosing schedule: it was based on a report on equivalencies of clinical dosages of risperidone, clozapine and chlorpromazine in adults. ${ }^{53)}$ Then we determined dosages

Table 1. Doses of metilphenidate allowed at randomization and during the trial in ADHD patients previously treated

\begin{tabular}{lcc}
\hline \multicolumn{1}{c}{ Variable } & Dose $(\mathrm{mg} / \text { day })^{*}$ & ${\text { Dose }(\mathrm{mg} / \text { day })^{\dagger}}^{\dagger}$ \\
\hline At randomization $(\mathrm{n}=12)$ & $39.6 \pm 18.9$ & $0.96 \pm 0.24$ \\
Risperidone $(\mathrm{n}=6)$ & $40.5 \pm 22.6$ & $0.94 \pm 0.16$ \\
Clozapine $(\mathrm{n}=6)$ & $38.7 \pm 16.7$ & $0.98 \pm 0.32$ \\
\hline
\end{tabular}

Values are presented as mean \pm standard deviation. ADHD, the attention deficit hyperactivity disorder. The $p$ values for intergroups are ${ }^{*} 0.81$ and ${ }^{\dagger} 1.00$. by applying the recommendation of maximal dosage of chlorpromazine in youth ${ }^{54)}$ to the previously mentioned clinical equivalence in adults, noting that no toxicity effects were reported in the literature for those levels, and that they made clinical sense.

\section{Statistical Analysis}

The MOAS has been used in research to document changes in aggressive behavior, and allows to measure the efficacy of various interventions, defining 'responders' as subjects who have a $50 \%$ decrease in aggressive behavior. $^{48)}$

The effect of risperidone on the Aggression Subscale of $\mathrm{CBCL}$ has been reported as -24.2 with a standard deviation of 5.7. ${ }^{13)}$ Assuming there would be a difference of 6 points between the groups (one treated with risperidone and the other with clozapine) with an alpha of 0.05 and a beta of 0.2 , at least 18 subjects needed to be randomized.

To verify randomization in balanced groups, basal distribution of demographic variables and scores of all the scales and subscales was compared to the variable medication. A Wilcoxon test was used to evaluate intragroup differences (final minus basal mean scores) to evaluate two-factor variances (time and medication) in 5 repeated scores along 16 weeks. Analysis was by intention-to-treat.

The Mann-Whitney $U$ test was used to evaluate whether clozapine efficacy was equal or better than risperidone in the treatment of aggression in conduct disorder. Type I error was controlled at 5\%. Confidence interval was 95\%. The $p$ value was used to determine differences between and within the groups. A $p \leq 0.05$ was considered statistically significant. JMP 12 statistical software (SAS Institute, Cary, NC, USA) was used to analyze data.

Table 2. Comorbidity diagnosis at randomization

\begin{tabular}{lccc}
\hline \multicolumn{1}{c}{ Diagnosis } & $\begin{array}{c}\text { All } \\
(\mathrm{n}=24)\end{array}$ & $\begin{array}{c}\text { Risperidone } \\
(\mathrm{n}=12)\end{array}$ & $\begin{array}{c}\text { Clozapine } \\
(\mathrm{n}=12)\end{array}$ \\
\hline $\begin{array}{l}\text { Comorbid diagnosis } \\
\text { Attention deficit } \\
\text { hyperactivity disorder }\end{array}$ & $24(100)$ & $12(100)$ & $12(100)$ \\
$\begin{array}{l}\text { Oppositional defiant } \\
\text { disorder }\end{array}$ & $23(91.7)$ & $12(100)$ & $10(83.3)$ \\
$\begin{array}{l}\text { Dysthimia/depression } \\
\text { Specific phobia }\end{array}$ & $3(12.5)$ & $2(16.7)$ & $1(8.3)$ \\
Other & $4(16.7)$ & $4(33.3)$ & $0(0)$ \\
\hline
\end{tabular}

Values are presented as number (\%). 


\section{RESULTS}

Sixty-five aggressive children and adolescents with conduct disorder were screened. Twenty-four were randomized to receive either clozapine or risperidone (Fig. 1). All had some form of comorbidity; the most common were ADHD (92\%) and ODD (96\%) (Table 2).

Subjects were predominantly male (92\%). Mean age of the 24 subjects was $10.6 \pm 2.6$ years; weight was $46 \pm 20.3$ $\mathrm{kg}$, height $150 \pm 0.17 \mathrm{~cm}$; education duration was $4.9 \pm 2.5$ years; intellectual coefficient was $91 \pm 10.6$. Demographic and baseline variables were compared between groups. Only white cell count had statistical significance where the risperidone group presented a lower count than the clozapine group $(6,607 \pm 1,302$ vs. 8,323 \pm 906 ; $p<0.001)$ (Table 3).

During the 16-week trial, three subjects from the risperidone group abandoned the study (two after week 1 and one after week 4); 2 subjects from the clozapine group abandoned the study (one after week 1 and one after week
12) (Fig. 1). Two more subjects were excluded due to a low neutrophil count at week 4 (59\% less and $81 \%$ less from baseline).

As a primary outcome, the MOAS score decreased more than $50 \%$ in both groups: risperidone $=-52 \%$; clozapine $=-58 \%$ which was statistically significant $(p=$ 0.011 and 0.003 , respectively). The difference in MOAS was higher in the risperidone group without statistical significance (18.3 \pm 22.3 vs. $16 \pm 11.6 ; p=0.582$ ) (Table 4). All subjects showed CBCL-E scores between 40 and 81 .

Intergroup analysis showed significant differences in CBCL-E where the clozapine group difference was higher $(30.3 \pm 9.6$ vs.17.7 $\pm 13.7 ; p=0.039)$ (Table 4).

As secondary outcomes, the Delinquency subscale and CGAS scores were also statistically different for the clozapine group ( $7.8 \pm 3.6$ vs. $3.7 \pm 3.1, p=0.01$ and $-28.8 \pm 18.5$ vs. $-9.7 \pm 18.9, p=0.021$, respectively).

CBCL-I, Aggression and Hyperactivity subscales differences were higher in clozapine group without meaningful difference from risperidone group $(25.8 \pm 10.5$ vs. $15 \pm 20$,

Table 3. Baseline characteristics of all children and adolescents randomized to treatment

\begin{tabular}{|c|c|c|c|c|}
\hline Characteristic & All $(n=24)$ & Risperidone ( $n=12$ ) & Clozapine $(n=12)$ & Intergroup $p$ value \\
\hline Sex & & & & 0.09 \\
\hline Male & $22(91.7)$ & $10(83.3)$ & $12(100)$ & \\
\hline Female & $2(8.3)$ & $2(16.7)$ & $0(0)$ & \\
\hline Age at evaluation (yr) & $10.6 \pm 2.6$ & $10.3 \pm 2.6$ & $10.9 \pm 2.6$ & 0.54 \\
\hline Male & $10.5 \pm 2.6$ & $10.0 \pm 2.7$ & $10.9 \pm 2.6$ & \\
\hline Female & $11.5 \pm 2.1$ & $11.5 \pm 2.1$ & - & \\
\hline Weight (kg) & $46 \pm 20.3$ & $45 \pm 20.7$ & $47 \pm 20.8$ & 0.80 \\
\hline Height $(\mathrm{cm})$ & $150 \pm 0.17$ & $149 \pm 0.17$ & $150 \pm 0.18$ & 0.88 \\
\hline Education $(y r)$ & $4.9 \pm 2.5$ & $4.5 \pm 2.2$ & $5.3 \pm 2.9$ & 0.44 \\
\hline Total intelectual coefficient & $91 \pm 10.6$ & $94 \pm 9.4$ & $89 \pm 11.7$ & 0.32 \\
\hline MOAS & $31.4 \pm 16.5$ & $35.4 \pm 17.1$ & $27.4 \pm 15.5$ & 0.24 \\
\hline CBCL-E & $64.0 \pm 10.5$ & $64.4 \pm 8.3$ & $63.6 \pm 12.8$ & 0.94 \\
\hline Agression & $32.0 \pm 5.8$ & $33.2 \pm 4$ & $30.9 \pm 7.0$ & 0.33 \\
\hline Hiperactivity & $12.9 \pm 3.9$ & $13.7 \pm 3.4$ & $12.2 \pm 4.4$ & 0.45 \\
\hline Delinquency & $12.0 \pm 5.6$ & $10.7 \pm 6.4$ & $13.5 \pm 4.5$ & 0.18 \\
\hline CBCL-I & $47.3 \pm 16.1$ & $52.0 \pm 19$ & $42.4 \pm 11.5$ & 0.27 \\
\hline CGAS & $39.4 \pm 7.1$ & $38.7 \pm 8.6$ & $40.2 \pm 5.5$ & 0.62 \\
\hline Hemoglobin (g/dl) & $13.9 \pm 0.8$ & $13.7 \pm 0.9$ & $14.1 \pm 0.7$ & 0.22 \\
\hline Leucocytes $(\mathrm{K} / \mu \mathrm{l})$ & $7,465 \pm 1,404$ & $6,607 \pm 1,302$ & $8,323 \pm 906$ & $<0.001$ \\
\hline Neutrophiles $(\mathrm{K} / \mu \mathrm{l})$ & $3,664 \pm 984$ & $3,301 \pm 1,019$ & $4,028 \pm 836$ & 0.07 \\
\hline Platelets $(\times 1,000 \mathrm{~K} / \mu \mathrm{l})$ & $271 \pm 50$ & $275 \pm 46$ & $267 \pm 55$ & 0.69 \\
\hline Glycemia (mg/dl) & $94.6 \pm 5.9$ & $94.9 \pm 6.2$ & $94.3 \pm 5.8$ & 0.81 \\
\hline Creatinine (mg/dl) & $0.49 \pm 0.2$ & $0.45 \pm 0.1$ & $0.53 \pm 0.3$ & 0.29 \\
\hline Urea nitrogen (mg/dl) & $9.9 \pm 3.0$ & $9.6 \pm 2.8$ & $10.2 \pm 3.3$ & 0.64 \\
\hline Urea $(\mathrm{mg} / \mathrm{dl})$ & $21.2 \pm 6.4$ & $20.4 \pm 5.9$ & $22.0 \pm 7.1$ & 0.56 \\
\hline
\end{tabular}

Values are presented as number (\%) or mean \pm standard deviation.

MOAS, Modified Overt Aggression Scale; CBCL-E, Child Behavior Checklist externalization factors; CBCL-I, Child Behavior Checklist internalization factors; CGAS, Children's Global Assessment Scale. 


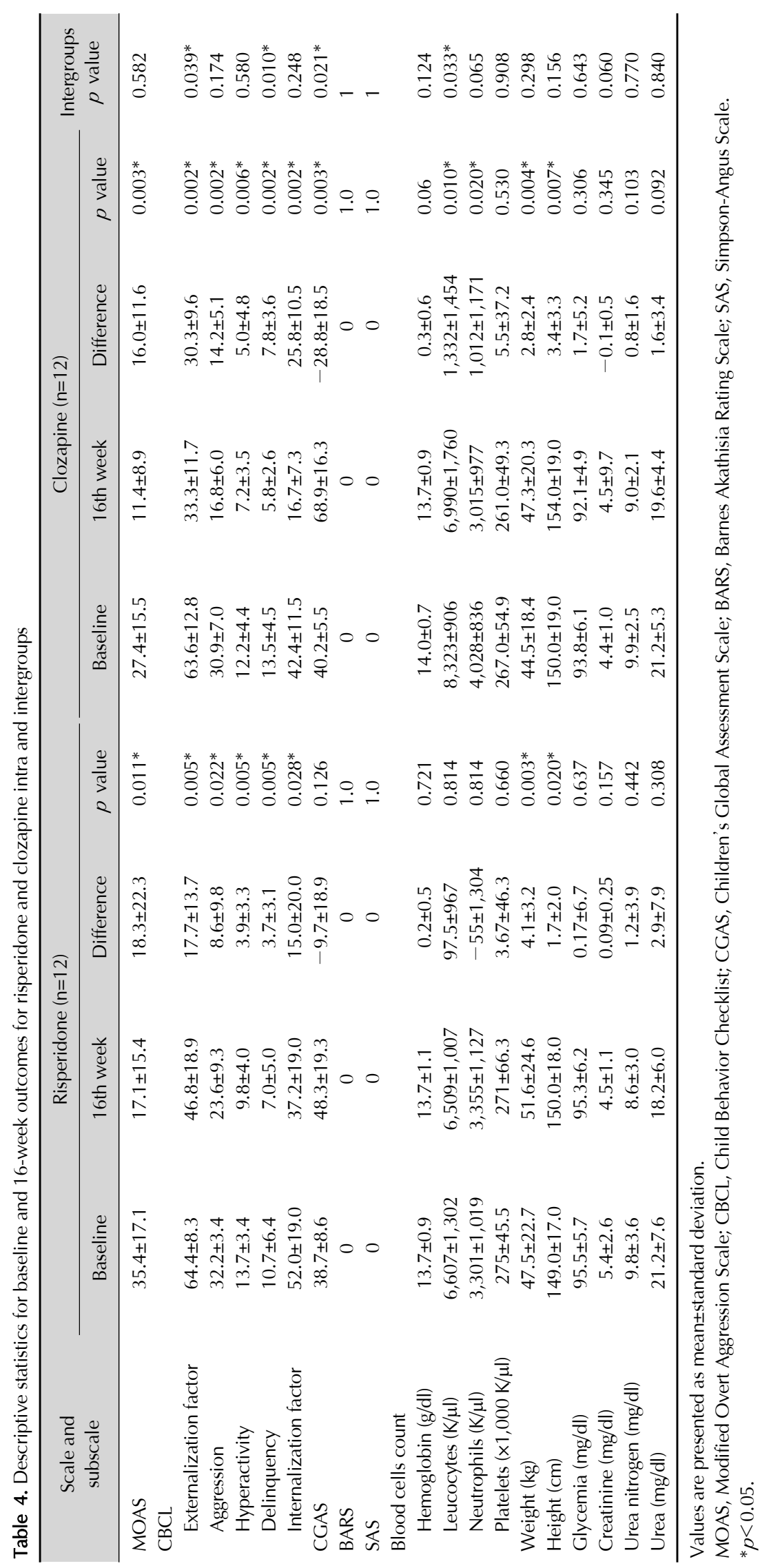


$p=0.248 ; 14.2 \pm 5.1$ vs. $8.6 \pm 9.8, p=0.174 ;$ and $5 \pm 4.8$ vs. $3.9 \pm 3.3, p=0.58$ ) (Table 4).

Baseline leucocyte cell counts presented a significant difference between groups with clozapine showing a higher count $(8,323 \pm 906$ vs. $6,607 \pm 1,302 \mathrm{~K} / \mu \mathrm{l}, p<$ 0.001 ) (Table 3). Baseline neutrophil cell counts in the clozapine group were also higher than the risperidone group but with no significant difference $(4,028 \pm 836$ vs. 3,301 $\pm 1,019 \mathrm{~K} / \mu \mathrm{l}, p=0.07$ ) (Table 3).

Between group comparison presented a significant difference in the leucocyte cell count with the risperidone group showing a smaller mean value than the clozapine group $(97.5 \pm 967 \mathrm{~K} / \mu \mathrm{l}$ vs. $1,332 \pm 1,454 \mathrm{~K} / \mu \mathrm{l}, p=0.033)$ without clinical significance. The difference in the neutrophil cell count was not significant $(1,012 \pm 1,171$ vs. $-55 \pm$ 1,304, $p=0.065$ ) (Table 4).

Between group analysis was not statistically meaningful for hemoglobin $(p=0.124)$, platelets counts $(p=0.908)$, weight ( $p=0.298)$, height $(p=0.156)$ and metabolic serum profile (glycemia, $p=0.643$; creatinine, $p=0.06$; urea nitrogen, $p=0.77$; and urea, $p=0.840$ ) (Table 4).

There were no signs of metabolic syndrome throughout the study. There were neither symptoms nor signs of adverse effects related to akathisia in either of the groups. BARS and SAS were zero in both groups ( $p=1.0$ ) (Table 4).

Somnolence, irritability, and increased appetite were the most incidental adverse events in both groups (Table 5).

Table 5. Incidence of adverse events observed in patients over the course of treatment.

\begin{tabular}{lllc}
\hline \multicolumn{1}{c}{ Variable } & $\begin{array}{c}\text { Risperidone } \\
(\mathrm{n}=12)\end{array}$ & $\begin{array}{c}\text { Clozapine } \\
(\mathrm{n}=12)\end{array}$ & $\begin{array}{c}\text { Total } \\
(\mathrm{n}=24)\end{array}$ \\
\hline Somnolence & $7(58.3)$ & $8(66.7)$ & $15(62.5)$ \\
Sedation/hypersomnia & 0 & $4(33.3)$ & $4(16.7)$ \\
Irritability & $8(66.7)$ & $6(50.0)$ & $14(58.3)$ \\
Hyposomnia & $3(25.0)$ & $1(8.3)$ & $4(16.7)$ \\
Hyperexia & $4(33.0)$ & $6(50.0)$ & $10(41.7)$ \\
Hyporexia & $1(8.3)$ & $0(0)$ & $1(4.2)$ \\
Sialorrhea & $1(8.3)$ & $0(0)$ & $1(4.2)$ \\
Abdominal pain & $3(25.0)$ & $0(0)$ & $3(12.5)$ \\
Constipation & $1(8.3)$ & $0(0)$ & $1(4.2)$ \\
Headache & $2(16.7)$ & $3(25.0)$ & $5(20.8)$ \\
Nausea & $1(8.3)$ & $2(16.7)$ & $3(12.5)$ \\
Anxiety & $3(25.0)$ & $1(8.3)$ & $4(16.7)$ \\
Dizziness & $2(16.7)$ & $1(8.3)$ & $3(12.5)$ \\
Stiff neck & $1(8.3)$ & $1(8.3)$ & $2(8.3)$ \\
Nocturnal urine voiding & $2(16.7)$ & $1(8.3)$ & $3(12.5)$ \\
Fainting & $1(8.3)$ & $1(8.3)$ & $2(8.3)$ \\
\hline
\end{tabular}

Values are presented as number (\%).
Vital signs throughout the entire study were not meaningfully different between the groups: respiratory rate, $p=0.13$; cardiac rate, $p=0.10$; arterial systolic pressure, $p=0.26$; and arterial diastolic pressure, $p=0.13$ (Table 6).

Within group outcomes were statistically meaningful in both groups for MOAS, CBCL-E, Aggression, Hyperactivity and Delinquency subscales and CBCL-I (risperidone group: $18.3 \pm 22.3, p=0.011 ; 17.7 \pm 13.7, p=0.005 ; 8.6 \pm$ $9.8, p=0.022 ; 3.9 \pm 3.3, p=0.005 ; 3.7 \pm 3.1, p=0.005$; and $15 \pm 20, p=0.028$ / clozapine group: $16 \pm 11.6, p=0.003$; $30.3 \pm 9.6, p=0.002 ; 14.2 \pm 5.1, p=0.002 ; 5 \pm 4.8, p=$ $0.006 ; 7.8 \pm 3.6, p=0.002 ;$ and $25.8 \pm 10.5, p=0.002$ ) (Table 4).

The CGAS score was significant for the clozapine group only $(-28.8 \pm 18.5, p=0.003$ vs. $-9.7 \pm 18.9, p=0.126)$ (Table 4).

The within group differences of white cell counts was higher in the clozapine group with statistical significance and without clinical significance $(1,332 \pm 1,454 \mathrm{~K} / \mu \mathrm{l}, p=$ 0.012 vs. 97.5 $\pm 967, p=0.814$ for leukocytes; $1,012 \pm$ $1,171, p=0.019$ vs. $-55 \pm 1,304, p=0.814$ for neutrophils) (Table 4).

The within group analysis at the end of the study was not statistically meaningful for hemoglobin (risperidone group: $0.2 \pm 0.5 \mathrm{~g} / \mathrm{dl}, p=0.721$; clozapine group: $0.3 \pm 0.6$ $\mathrm{g} / \mathrm{dl}, p=0.06$ ), platelets (risperidone group: $3.67 \times 10^{3} \pm$ $46.3 \times 10^{3} \mathrm{~K} / \mu \mathrm{l}, p=0.66$; clozapine group: $5.5 \times 10^{3} \pm 37.2 \times$ $10^{3} \mathrm{~K} / \mu \mathrm{l}, p=0.53$ ) and biochemical profile (glycemia [risperidone group: $0.17 \pm 6.7 \mathrm{mg} / \mathrm{dl}, p=0.637$; clozapine group: $1.7 \pm 5.2 \mathrm{mg} / \mathrm{dl}, p=0.306$ ], creatinine [risperidone group: $0.09 \pm 0.25 \mathrm{mg} / \mathrm{dl}, p=0.157$; clozapine group: $-0.1 \pm$ $0.5 \mathrm{mg} / \mathrm{dl}, p=0.345$ ], urea nitrogen [risperidone group: $1.2 \pm 3.9 \mathrm{mg} / \mathrm{dl}, \quad p=0.442$; clozapine group: $0.8 \pm 1.6$ $\mathrm{mg} / \mathrm{dl}, p=0.103$ ], and urea [risperidone group: $2.9 \pm 7.9$ $\mathrm{mg} / \mathrm{dl}, p=0.308$; clozapine group: $1.6 \pm 3.4 \mathrm{mg} / \mathrm{dl}, p=$ 0.092]) as shown on Table 4.

Weight and height were significantly different in the in-

Table 6. Vital signs intergroup comparisson

\begin{tabular}{lcccc}
\hline \multicolumn{1}{c}{ Sign } & $\begin{array}{c}\text { All } \\
(\mathrm{n}=24)\end{array}$ & $\begin{array}{c}\text { Risperidone } \\
(\mathrm{n}=12)\end{array}$ & $\begin{array}{c}\text { Clozapine } \\
(\mathrm{n}=12)\end{array}$ & $p$ value \\
\hline Respiratory rate & $22 \pm 3$ & $21 \pm 3$ & $22 \pm 2$ & 0.13 \\
Cardiac rate & $83 \pm 10$ & $86 \pm 9$ & $80 \pm 10$ & 0.10 \\
Systolic $(\mathrm{mmHg})$ & $104 \pm 14$ & $105 \pm 11$ & $103 \pm 17$ & 0.26 \\
Diastolic $(\mathrm{mmHg})$ & $64 \pm 8$ & $66 \pm 7$ & $61 \pm 8$ & 0.13 \\
\hline
\end{tabular}

Values are presented as mean \pm standard deviation. 
tragroup analysis at the end of the study $(4.1 \pm 3.2 \mathrm{~kg}$, $p=0.003$ and $1.7 \pm 2 \mathrm{~cm}, p=0.02$ for the risperidone group; $2.8 \pm 2.4 \mathrm{~kg}, p=0.004$ and $3.4 \pm 3.3 \mathrm{~cm}, p=0.007$ for the clozapine group) (Table 4 ).

\section{DISCUSSION}

Clozapine use in treating aggression in conduct disorder has not been suitably studied. There is no evidence in the literature that showed any double-blind clinical trials in children and adolescents.

Our results showed both antipsychotics to be similarly effective in reducing MOAS scores in subjects with conduct disorder. Subjects' aggressive scores decreased more than a $50 \%$; therefore, they were considered responders. The secondary endpoints, CBCL and CGAS showed decreased scores also with clinical significance. ${ }^{1,15,16,24,35,36,38,41)}$

As a part of the secondary analysis, $\mathrm{CBCL}$ subscales scores were compared between treatment groups, and clozapine was more effective than risperidone in conduct externalization factors (particularly Delinquency) and in global functioning (CGAS). If this result is related to their differing mechanisms of action, it remains to be determined in further studies. ${ }^{24)}$

Doses used in this study were good enough to improve symptoms without adverse effects in this first 16 -week treatment $(0.6 \mathrm{mg} / \mathrm{kg}$ for clozapine; $0.05 \mathrm{mg} / \mathrm{kg}$ for risperidone).

There was no akathisia or signs of metabolic syndrome.

As expected, the most frequently observed adverse events were somnolence, irritability and increased appetite. ${ }^{1)}$ Two subjects (one treated with clozapine and the other with risperidone) withdrew due to somnolence; two more treated with risperidone did not continue with the trial because of their mothers' health/labor problems; one more treated with clozapine did not show up after week 4 . Therefore, the dropout rate in this study was $29 \%$ ( $21 \%$ desertions; $8 \%$ due to neutropenia). This result may highlight the difficulty of maintaining continuous treatment in this type of pathology. Neutropenia may be related to pharmacogenomic aspects that were not explored. Immune-mediated response against neutrophils, enhanced apoptosis of neutrophils and direct toxicity against bone marrow stromal cells are possible mechanisms of clozapine-induced neutropenia/agranulocytosis, occuring more than a half of the time within the first 18 weeks of treatment. ${ }^{31,32)}$ Reduction in viability of lymphoblast cell lines induced by clozapine is a heritable, polygenic trait. ${ }^{33)}$ Risk for clozapine-induced agranulocytosis/granulocytopenia can be predicted through pharmacogenomic and microsomal incubations studies. ${ }^{35,55)}$ Demographic risk factors reported for healthy children and adolescents are males, younger age and African American ethnicity. ${ }^{56)}$

Intergroup difference showed statistical significance in leukocyte count ( $p=0.033$ ). This effect may be due to different baseline cell counts of clozapine and risperidone with statistical significance between groups $(p \leq 0.001$, Table 3), so we can say that between group differences are not of clinical significance. Weight arousal into both groups was significant due to greater appetite as an adverse event with no nutritional control. Weight and height differences were not different between groups as expected. ${ }^{57)}$

Clozapine showed greater efficacy than risperidone in short-term treatment improving global conduct externalization factors, the Delinquency subscale and global functioning in conduct disorder. The Aggression and Hyperactivity subscales improvement was greater in the clozapine group and the improvement in the MOAS score was greater in the risperidone group. Neither one was statistically significant. It is our suggestion that stronger efficacy of clozapine should be investigated in a larger sample, with pre-study pharmacogenomic studies so the risk of leukopenia can be identified.

The limitations of this study are as follows; dynamic systems of family and social environment were not evaluated as a probable influence on score rates. Even when initial statistical analysis showed a number of at least 18 subjects to be randomized, twenty-four seemed to be a small sample size to consolidate conclusions.

\section{- Acknowledgments}

Paper was accepted to be presented at 2018 Annual meeting of the American Society of Hispanic Psychiatry "Migration and Mental Health," that will take place in New York City on May 5, 2018 at 13:00. The project was supported by the Seguro Popular (Mexican National Health Insurance) through the grants of the Hospital Regional Materno-Infantil de Alta Especialidad (File \# 06/2014) and by the Pl's personal funds. Work was done at Department of Pediatrics, Hospital Regional Materno- 
Infantil de Alta Especialidad, Servicios de Salud de Nuevo León, México. Affiliated to Universidad Autónoma de Nuevo León, Facultad de Medicina, México.

Very special thanks to the Pediatrics Department staff of the Hospital Regional de Alta Especialidad Materno-Infantil, Nuevo León, Mexico: Dr. Roberto F. Reyna Garza, Chairman of the Pediatrics Department, Lic. Olga de Osio Rodríguez and Lic. Jakeline Ortega V., Psychologists; Ms. Laura Moya Quintanilla, Head Nurse; Ms. Minerva Martínez Buentello, Nurse/Electroencephalogram Technician and Ms. Lucía M. González Juárez, Administrator who without their support this work could not have been done. We also thank Sergio Lozano-Rodriguez, M.D. for his critical review of the manuscript.

\section{REFERENCES}

1. Loy JH, Merry SN, Hetrick SE, Stasiak K. Atypical antipsychotics for disruptive behavior disorders in children and youths. Cochrane Database Syst Rev 2017;(9):CD008559.

2. Thomas CR. Chapter 11. Oppositional defiant disorder and conduct disorder. In: Dulcan MK, editor. Dulcan's textbook of child and adolescent psychiatry. 2nd ed. Arlington, VA:American Psychiatric Association Publishing;2016. p. 195-218.

3. Gurnani T, Ivanov I, Newcorn JH. Pharmacotherapy of aggression in child and adolescent psychiatric disorders. J Child Adolesc Psychopharmacol 2016;26:65-73.

4. Pringsheim T, Hirsch L, Gardner D, Gorman DA. The pharmacological management of oppositional behaviour, conduct problems, and aggression in children and adolescents with attention-deficit hyperactivity disorder, oppositional defiant disorder, and conduct disorder: a systematic review and meta-analysis. Part 2: Antipsychotics and traditional mood stabilizers. Can J Psychiatry 2015;60:52-61.

5. Costello EJ, Egger H, Angold A. 10-year research update review: the epidemiology of child and adolescent psychiatric disorders: I. Methods and public health burden. I Am Acad Child Adolesc Psychiatry 2005;44:972-986.

6. Medina-Mora ME, Borges G, Lara Muñoz C, Benjet C, Blanco James J, Fleiz Bautista C, et al. [Prevalence of mental disorders and use of services: Results of national survey of psychiatric epidemiology in Mexico]. Salud Ment 2003;26:1-16. Spanish.

7. Dayton CJ, Malone JC. Development and socialization of physical aggression in very young boys. Infant Ment Health J 2017;38:150-165.

8. Schur SB, Sikich L, Findling RL, Malone RP, Crismon ML, Derivan A, et al. Treatment recommendations for the use of antipsychotics for aggressive youth (TRAAY). Part I: a review. J Am Acad Child Adolesc Psychiatry 2003;42:132-144.

9. Pappadopulos E, Macintyre Ii JC, Crismon ML, Findling RL,
Malone RP, Derivan A, et al. Treatment recommendations for the use of antipsychotics for aggressive youth (TRAAY). Part II. J Am Acad Child Adolesc Psychiatry 2003;42:145-161.

10. Cheng-Shannon J, McGough JJ, Pataki C, McCracken JT. Second-generation antipsychotic medications in children and adolescents. / Child Adolesc Psychopharmacol 2004; 14:372-394.

11. Findling RL, Reed MD, O'Riordan MA, Demeter CA, Stansbrey RJ, McNamara NK. Effectiveness, safety, and pharmacokinetics of quetiapine in aggressive children with conduct disorder. J Am Acad Child Adolesc Psychiatry 2006;45: 792-800.

12. Findling RL, Frazier JA, Gerbino-Rosen G, Kranzler HN, Kumra S, Kratochvil CJ. Is there a role for clozapine in the treatment of children and adolescents? I Am Acad Child Adolesc Psychiatry 2007;46:423-428.

13. Steiner H, Remsing L; Work Group on Quality Issues. Practice parameter for the assessment and treatment of children and adolescents with oppositional defiant disorder. I Am Acad Child Adolesc Psychiatry 2007;46:126-141.

14. McVoy M, Findling R. Child and adolescent psychopharmacology update. Psychiatr Clin North Am 2009;32:111-133.

15. Teixeira EH, Jacintho A, Celeri HV, Dalgalarrondo P. Atypical antipsychotics in the treatment of pathological aggression in children and adolescents: literature review and clinical recommendations. Trends Psychiatry Psychother 2013;35: 151-159.

16. Teixeira EH, Celeri EV, Jacintho AC, Dalgalarrondo P. Clozapine in severe conduct disorder. I Child Adolesc Psychopharmacol 2013;23:44-48.

17. Brown D, Larkin F, Sengupta S, Romero-Ureclay JL, Ross CC, Gupta N, et al. Clozapine: an effective treatment for seriously violent and psychopathic men with antisocial personality disorder in a UK high-security hospital. CNS Spectr 2014;19: 391-402.

18. Stahl SM. [Antipsicóticos agentes]. In: Stah/ SM, editor. [Sthal's essential psychopharmacology: neuroscientific basis and practical application]. 4th ed. Madrid:Grupo Aula Médica, S.L.j2014. p.180-202. Spanish.

19. Kant R, Chalansani R, Chengappa KN, Dieringer MF. The off-label use of clozapine in adolescents with bipolar disorder, intermittent explosive disorder, or posttraumatic stress disorder. J Child Adolesc Psychopharmacol 2004; 14:57-63.

20. McEvoy JP, Lieberman JA, Stroup TS, Davis SM, Meltzer HY, Rosenheck RA, et al. Effectiveness of clozapine versus olanzapine, quetiapine, and risperidone in patients with chronic schizophrenia who did not respond to prior atypical antipsychotic treatment. Am J Psychiatry 2006;163:600-610.

21. Sauvaget A, Tollec C, Augy J, Guitteny M, Vanelle JM. Anti-aggressiveness effects of clozapine on complex neuropsychiatric pathologies. Ann Méd Psychol 2009;167:285289.

22. Lambrey S, Falissard B, Martin-Barrero M, Bonnefoy C, 
Quilici G, Rosier A, et al. Effectiveness of clozapine for the treatment of aggression in an adolescent with autistic disorder. J Child Adolesc Psychopharmacol 2010;20:79-80.

23. Asenjo Lobos C, Komossa K, Rummel-Kluge C, Hunger $\mathrm{H}$, Schmid F, Schwarz S, et al. Clozapine versus other atypical antipsychotics for schizophrenia. Cochrane Database Sust Rev 2010; (11):CD006633.

24. Frogley C, Taylor D, Dickens G, Picchioni M. A systematic review of the evidence of clozapine's anti-aggressive effects. Int J Neuropsychopharmacol 2012;15:1351-1371.

25. Sanz-Fuentenebro J, Taboada D, Palomo T, Aragües M, Ovejero S, Del Alamo C, et al. Randomized trial of clozapine vs. risperidone in treatment-naive first-episode schizophrenia: results after one year. Schizophr Res 2013;149: 156-161.

26. Fitzpatrick SE, Srivorakiat L, Wink LK, Pedapati EV, Erickson CA. Aggression in autism spectrum disorder: presentation and treatment options. Neuropsychiatr Dis Treat 2016;12:15251538.

27. Solmi M, Murru A, Pacchiarotti I, Undurraga J, Veronese N, Fornaro M, et al. Safety, tolerability, and risks associated with first- and second-generation antipsychotics: a state-of-the-art clinical review. Ther Clin Risk Manag 2017;13:757-777.

28. Kapur S, Seeman P. Does fast dissociation from the dopamine $d(2)$ receptor explain the action of atypical antipsychotics?: A new hypothesis. Am J Psychiatry 2001;158:360-369.

29. Natesan S, Reckless GE, Barlow KB, Nobrega JN, Kapur S. Amisulpride the 'atypical' atypical antipsychotic-comparison to haloperidol, risperidone and clozapine. Schizophr Res 2008; 105:224-235.

30. Gerbino-Rosen G, Roofeh D, Tompkins DA, Feryo D, Nusser $\mathrm{L}$, Kranzler $\mathrm{H}$, et al. Hematological adverse events in clozapine-treated children and adolescents. I Am Acad Child Adolesc Psychiatry 2005;44:1024-1031.

31. Nooijen PM, Carvalho F, Flanagan RJ. Haematological toxicity of clozapine and some other drugs used in psychiatry. Hum Psychopharmacol 2011;26:112-119.

32. Cohen D, Monden M. White blood cell monitoring during long-term clozapine treatment. Am J Psychiatry 2013;170: 366-369.

33. de With SA, Pulit SL, Wang T, Staal WG, van Solinge WW, de Bakker PI, et al. Genome-wide association study of lymphoblast cell viability after clozapine exposure. Am J Genet B Neuropsychiatr Genet 2015;168B:116-122.

34. Saito T, Ikeda M, Mushiroda T, Ozeki T, Kondo K, Shimasaki A, et al. Pharmacogenomic study of clozapine-induced agranulocytosis/granulocytopenia in a Japanese population. Biol Psychiatry 2016;80:636-642.

35. Findling RL, McNamara NK, Branicky LA, Schluchter MD, Lemon E, Blumer JL. A double-blind pilot study of risperidone in the treatment of conduct disorder. I Am Acad Child Adolesc Psychiatry 2000;39:509-516.

36. Turgay A, Binder C, Snyder R, Fisman S. Long-term safety and efficacy of risperidone for the treatment of disruptive behavior disorders in children with subaverage IQs. Pediatrics 2002; 110:e34.

37. Croonenberghs J, Fegert JM, Findling RL, De Smedt G, Van Dongen S; Risperidone Disruptive Behavior Study Group. Risperidone in children with disruptive behavior disorders and subaverage intelligence: a 1-year, open-label study of 504 patients. I Am Acad Child Adolesc Psychiatry 2005;44: 64-72.

38. Reyes M, Buitelaar J, Toren P, Augustyns I, Eerdekens M. $A$ randomized, double-blind, placebo-controlled study of risperidone maintenance treatment in children and adolescents with disruptive behavior disorders. Am I Psychiatry 2006; 163:402-410.

39. Pandina GJ, Bilder R, Harvey PD, Keefe RS, Aman MG, Gharabawi G. Risperidone and cognitive function in children with disruptive behavior disorders. Biol Psychiatry 2007;62: 226-234.

40. Aman MG, Bukstein OG, Gadow KD, Arnold LE, Molina BS, McNamara NK, et al. What does risperidone add to parent training and stimulant for severe aggression in child attention-deficit/hyperactivity disorder? I Am Acad Child AdolesC Psychiatry 2014;53:47-60.e1.

41. Gadow KD, Arnold LE, Molina BS, Findling RL, Bukstein OG, Brown NV, et al. Risperidone added to parent training and stimulant medication: effects on attention-deficit/hyperactivity disorder, oppositional defiant disorder, conduct disorder, and peer aggression. I Am Acad Child Adolesc Psychiatry 2014;53:948-959.e1.

42. Gadow KD, Brown NV, Arnold LE, Buchan-Page KA, Bukstein $\mathrm{OG}$, Butter $\mathrm{E}$, et al. Severely aggressive children receiving stimulant medication versus stimulant and risperidone: 12-month follow-up of the TOSCA trial. I Am Acad Child Adolesc Psychiatry 2016;55:469-478.

43. Demirkaya SK, Aksu H, Özgür BG. A retrospective study of long acting risperidone use to support treatment adherence in youth with conduct disorder. Clin Psychopharmacol Neurosci 2017; 15:328-336.

44. Ardic UA, Küçükköse M, Inci SB, Ercan ES. Efficacy and safety profile of risperidone long-acting injection in adolescents in a real-life setting. Clin Psychopharmacol Neurosci 2018;16: 57-61.

45. American Psychiatric Association. Diagnostic and statistical manual of mental disorders. 4th ed, revised. Washington, D.C.: American Psychiatric Association;2000.

46. Yudofsky SC, Silver JM, Jackson W, Endicott J, Williams D. The Overt Aggression Scale for the objective rating of verbal and physical aggression. Am J Psychiatry 1986;143:35-39.

47. Kay SR, Wolkenfeld F, Murrill LM. Profiles of aggression among psychiatric patients. I. Nature and prevalence. I Nerv Ment Dis 1988;176:539-546.

48. Silver JM, Yudofsky SC. The Overt Aggression Scale: overview and guiding principles. I Neuropsychiatry Clin Neurosci 
1991;3:S22-S29.

49. Garcia S, Massa EP, Muñiz Fernández JL. El cuestionario CBCL de Achenbach: Adaptación española y aplicaciones clínico-epidemiológicas [Achenbach's CBCL questionnaire: Spanish adaptation and clinical-epistemological applications]. Clínica y Salud 1997;8:447-480. Spanish.

50. Shaffer D, Gould MS, Brasic J, Ambrosini P, Fisher P, Bird H, et al. A children's global assessment scale (CGAS). Arch Gen Psychiatry 1983;40:1228-1231.

51. Barnes TR. A rating scale for drug-induced akathisia. Br J Psychiatry 1989;154:672-676.

52. Simpson GN, Angus JW. A rating scale for extrapyramidal side effects. Acta Psychiatr Scand 1970;212:11-19.

53. MD Consult. Clozapine [Internet]. MD Consult/Drug Monograph; 2013 [cited at 2013 Oct]. Available from: nuw.mdconsult.com das/pharm/body/428692759-4/0/full/142.
54. Meditodo. Clorpromazina [Internet]. Lima, Perú: Lab. AC Farma S.A. [cited at 2013 Oct 29]. Available from: https://meditodo.com/medicamento/clorpromazina-ac-farma.

55. Tschen AC, Rieder MJ, Oyewumi LK, Freeman DJ. The cytotoxicity of clozapine metabolites: implications for predicting clozapine-induced agranulocytosis. Clin Pharmacol Ther 1999;65:526-532.

56. Maher KN, Tan M, Tossell JW, Weisinger B, Gochman P, Miller R, et al. Risk factors for neutropenia in clozapine-treated children and adolescents with childhood-onset schizophrenia. J Child Adolesc Psychopharmacol 2013;23: 110-116.

57. Maayan L, Correll CU. Weight gain and metabolic risks associated with antipsychotic medications in children and adolescents. J Child Adolesc Psychopharmacol 2011;21: 517-535. 